\title{
Activities test of Mahkota Dewa (Phaleria macrocarpa) leaves extract against Candida albicans of HIV/AIDS patients
}

\author{
Dewi Elianora*, Busman**, Yeri Amrillya** \\ *Department of Pedodontics Faculty of Dentistry Universitas Baiturrahmah \\ ${ }^{* *}$ Department of Oral Biology Faculty of Dentistry Universitas Baiturrahmah
}

\begin{abstract}
Introduction: Candida albicans is a local commensal flora of the oral cavity, with opportunistic nature and often causes oral candidiasis in HIV/AIDS patients. Since long time, Mahkota Dewa (Phaleria macrocarpa) known of having efficacy to treat various disease traditionally. The purpose of this study was to determine the activity test of Phaleria macrocarpa leaves extract against Candida albicans from HIV/AIDS patients. Methods: Experimental laboratory with samples colonies of the Candida albicans fungus obtained from patients with HIV/AIDS at Dr. M. Djamil General Hospital Padang. Research conducted during JanuaryMarch 2016 in Microbiology and Chemistry Laboratory of Kopertis Region X, Microbiology Laboratory of Dr. M. Djamil General Hospital, and Microbiology Laboratory of Siti Rahmah Islamic Hospital, Padang, West Sumatra. Data was analyzed using the Kruskal-Wallis test. Results: The concentration of the Phaleria Macrocarpa leaves extract used in this study was 10, 20, 40 and $80 \%$. Inhibition zone average value obtained $0,00 \mathrm{~mm}$, means no inhibition zone, $9.217 \mathrm{~mm}$ and $18.017 \mathrm{~mm}$ with $\mathrm{sig}=0.000<0.05$. Conclusion: The higher level of the Phaleria macrocarpa leaves extract concentration, the higher inhibition zone diameter against Candida albicans, with the highest in concentration $80 \%$.
\end{abstract}

Keywords: Mahkota Dewa (Phaleria macrocarpa) leaves extract, Candida albicans, HIV/AIDS

P-ISSN 1979-0201, e-ISSN 2549-6212 Available from:http://jurnal.unpad.ac.id/pjd/index

DOI:http://dx.doi.org/10.24198/pjd.vol29no1.11588

Submission: Jan 2017 Publishing: March 2017

\section{INTRODUCTION}

Indonesia has many traditional medicine that can be used as an alternative treatment, but unexamined scientifically. One of them is Mahkota dewa (Phaleria Marcocarpa). ${ }^{1}$ Phaleria macrocarpa is a traditional medicinal plant that has been known for long and increasingly enthused, with efficacy healing sores, diabetes, influenza, allergies, asphyxia, dysentery, cancer, and also skin, cardiac, and kidney diseases. The therapeutic effect of Phaleria macrocarpa closely related to the chemical compounds contained inside. It is known that only Phaleria macrocarpa grains are toxic, not including it's pulp. The highest inhibitory potention of Phaleria macrocarpa contained in its pulp, rather than the roots, barks, and leaves. ${ }^{1,2}$

Phaleria macrocarpa leaves contains anti histamines, alkaloids, saponins, and polyphenols 
(lignans). ${ }^{3}$ Saponin is a glycosides found from natural sources and can be detected by their ability to form a foam once whipped with a liquid solvent. In plants, saponin functionate as a reserved form of carbohydrates, waste product of metabolism, as well as protection against insect attack. Saponin is an antimicrobial agent against bacteria, viruses, fungi, and yeast. ${ }^{4}$ The active ingredient of Phaleria macrocarpa pulp is tannins, flavonoids, saponins, and alkaloids. ${ }^{2}$

The prior literature has mentioned that genera Phaleria plantation generally has an antimicrobial activity due to compounds inside. Yunanto ${ }^{5}$ has done research on infusum inhibition zone test of Phaleria macrocarpa leaves against Streptococcus mutans growth. The results showed that Phaleria macrocarpa leaves infusum have the ability to inhibit the growth with the highest inhibition at concentrations of $50 \%$. Suryani and Selly ${ }^{6}$ research showed that Phaleria macrocarpa leaves infusum has antibacterial power against Staphylococcus aureus with Minimum Inhibitory Concentration (MIC) 3.125 gram\% and Minimum Killing Concentration (MKC) 6.25 gram\%, also, had not antibacterial power against Eschericia coli with MIC greater than 25 gram\%.

From Wulandari ${ }^{7}$ research obtained that antibacterial substances contained in the Phaleria macrocarpa pulp are tannin, saponins, flavonoids, alkaloids, sterols, and terpenoid. Rostinawati ${ }^{8}$ research showed that Phaleria macrocarpa has an antibacterial effect against Staphylococcus aureus, Pseudomonas aeruginosa, Streptococcus sp., Escheria coli, and Salmonella thypi, whilst against Candida albicans showed no antifungal activity. Candida albicans is one of the microorganisms that act as normal flora in the human body and also not harmful, but causes most infections in human, mostly localized infection such as oral and vaginal infections. ${ }^{9}$

Many fungal infection caused by Candida species, especially Candida albicans. There are about $30-40 \%$ in healthy adults oral cavity, $45 \%$ in neonates, $45-65 \%$ in healthy children, $50-65 \%$ in patients using removable denture, $65-88 \%$ in patients with long-term medication, $90 \%$ in patients with acute leukemia whose undergo chemotherapy, and $95 \%$ in HIV/AIDS patients. ${ }^{10}$

Oral candidiasis is co-infection that is most common in patients with HIV/AIDS. Although the pathogenesis always associated with decrease in patient's immune system, but the real mechanism has not clear yet. Candida albicans is commensal flora of the oral cavity with the opportunistic nature. The formation of hyphae is a transformation sign of microorganism nature from commensal becoming pathogenic. ${ }^{11}$

AIDS (Acquired Immunodeficiency Syndro$m e$ ) is a set of symptoms or infections caused by HIV (Human Immunodeficiency Virus). HIV attacks the immune system, causing a decrease in patient endurance. In patients with AIDS, a decrease in the immune system is closely related to the occurrence of opportunistic infections. Cumulatively, AIDS cases in Indonesia since April 1, 1987 until December 31, 2011 were as much as 29.879 cases, with death rate was 5430 patients. Based on gender classification, AIDS cases found mostly in men with 20.333 cases, whilst in women found only 8.122 cases. ${ }^{12}$ Based on references from previous research, further researchers have done about activities test of Phaleria macrocarpa leaves extract against Candida albicans of HIV/ AIDS patients.

\section{METHODS}

Tools used in this study were scissors, petri dish, large bottle, rotary funnel, porcelain bowl, bath autoclave, test tubes, paper disc, Whatman filter paper, glass rods, incubator, measuring cup, Erlenmeyer flask, digital scales, glass funnel, aluminum foil, plastic wrap, sterile cotton bud, test tubes, rubbing alcohol, inoculating loop, glass slides, microscope, ruler, rotary evaporator, tongue spatel, mask, handscoon, and tissue. Materials used in this study were Phaleria macrocarpa leaves extract, ethanol $96 \%$, aquades, Ketoconazole, physiological solution $(\mathrm{NaCl} 0.9 \%)$, Alcohol 70\%, coloring materials, and Dimethyl Sulfoxide (DMSO).

Phaleria macrocarpa leaves that obtained from Naniang River Village, Bukit Barisan District, was extracted. The fresh leaves washed with clean water, then being wind dried for 10 days. After that, it was inserted into a dark bottle with the size of 2.5 liters, and poured with 2 liters of ethanol $96 \%$ by using a glass funnel. Then, it was tightly sealed by a bottle cap. It was stirred every single day. A week after, Phaleria macrocarpa 
Table 1. The making of the Phaleria macrocarpa leaves extract solution concentration

\begin{tabular}{cccc}
\hline $\begin{array}{c}\text { DMSO } \\
\text { (Ml) }\end{array}$ & $\begin{array}{c}\text { Extract } \\
\text { (Gr) }\end{array}$ & $\begin{array}{c}\text { Final volume } \\
\text { (Ml) }\end{array}$ & $\begin{array}{c}\text { Concentration } \\
\text { (\%) }\end{array}$ \\
\hline 9 & 1 & 10 & 10 \\
8 & 2 & 10 & 20 \\
6 & 4 & 10 & 40 \\
2 & 8 & 10 & 80 \\
\hline
\end{tabular}

maceration immersion filtered using a cotton coated glass funnel to be inserted into Erlenmeyer flask so ethanol extract filtrate can be obtained.

In order to obtain a thick extract then evaporated using a rotary evaporator. After obtained a viscous extract, then poured into a porcelain bowl and evaporated again with bath. Aerated at room temperature afterwards. The extraction process was completed and obtained a viscous extract of Phaleria macrocarpa leaves. Phaleria macrocarpa leaves solution concentration used in this study were $10,20,40$ and $80 \%$ (Table 1 ).

The medium (Sabouraud Dextrose Agar) making done by adding $6.5 \mathrm{gr}$ of Sabouraud Dextrose Agar powder with $100 \mathrm{ml}$ aquadest. Both were mixed and then heated until boiled and then cover with gauze containing cotton. Medium and tools that will be used sterilized in the autoclave for 15 minutes at $121^{\circ} \mathrm{C}$. Liquid Sabouraud Dextrose Agar as a medium poured into a sterilized petri dish as high as $5-6 \mathrm{~mm}$ and let stand until solidified. Candida albicans proliferation was done by collecting specimens on HIV/AIDS patients tongue by using sterile cotton bud. The basting was done by using a cotton bud in Sabouraud Dextrose Agar medium, incubated for 24 hours to getting a perfect accretion of Candida albicans.

This fungus specimen collected using inoculating loop, then basted on Sabouraud medium tester. The tip of inoculating loop then burned by using methylated spirit burner, chilled in Sabouraud Dextrose Agar medium afterwards. Scratched into four parts and do gram stain to ensure the growing mold. Then burn again the inoculating loop tip until the color turned red.

The planted specimens then inserted into an incubator for 48 hours at $37^{\circ} \mathrm{C}$. If the visible colonies on Sabouraud Dextrose Agar shaped round, ellipse, or oval, with a slightly convex and smooth surface and sometimes slightly overlapped, and had the smell of yeast, then the colonies were identified as Candida albicans.

Candida albicans identification was done by using gram stain. One inoculating loop contained Candida albicans culture placed on the top of a glass object, dripped with 1 drop of normal saline $(0.9 \% \mathrm{NaCl})$, and poured with gentian violet carbolic dye, then let stand for 1 minute. The dye was then removed and immediately dropped with lugol (without being washed first), let stand again for 1 minute. Afterwards, lugol disposed and the preparation was washed with $96 \%$ alcohol until no more color was dissolved. The glass object then washed with flowing water until clean, and poured with fuchsin solution, let stand for 1 minute. Washed again with running water until clean. Pat dry with filter paper. Observed under the microscope with the objective lens. On microscope observation will seen Candida albicans having ellipse, small, thin walled yeast, with sprout, and having a violet color (indicating classified to the gram-positive).

The germ tube was done by putting one inoculating loop contained germ into a sterile petri dish that has been filled with egg white. Then incubated for 3 hours in an incubator. Observed under a microscope to see the germ tube. The number of repetitions for antifungal activity test conducted in this study was calculated using the Federer general formula. The number of treatment groups in the study were 4 treatments and repeated 6 times, so the sample numbers became 24 treatment. Thus, to fulfill the requirements of a statistical test, required 6 repetitions using one kind of Candida albicans sample. ${ }^{13}$

Testing of antifungal activity using agar diffusion method which was making Sabouraud Dextrose Agar (SDA) media which has been basted with Candida albicans in a petri dish. Afterwards, placed paper disc that has been soaked in a concentrated solution, with one petri contained 4 discs with the same concentration, that was the concentration of $10,20,40$ and $80 \%$. For positive control, $200 \mathrm{mg}$ of ketoconazole $200 \mathrm{mg}$ were placed into one piece of paper disc in a petri. The entire petri incubated at $37^{\circ} \mathrm{C}$ for 48 hours. Limpid zone seen around the paper disc was then measured using a caliper. 


\section{RESULTS}

On the research it seen that the visible colonies on Sabouraud Dextrose Agar having the round, ellipse, or oval shape, with a slightly convex and smooth surface and sometimes slightly overlapped, and had the smell of yeast, then the colonies were identified as Candida albicans (Fig. 1).

From gram-positive stain results, Candida albicans found in the form of yeast, oval shaped, with approximately $5 \mu \mathrm{m}$ diameter, and reproduced by forming bud (Fig. 2). This kind of fungus often found in the form of mycelium with pseudohyphae. ${ }^{14}$ Germ Tube formation (sprout) test also can be used to identifying Candida albicans species. On germ tube test, the medium used was protein factor contained materials, such as egg white. On this research, medium used was egg white which before used placed in an incubator at a temperature of $37^{\circ} \mathrm{C}$

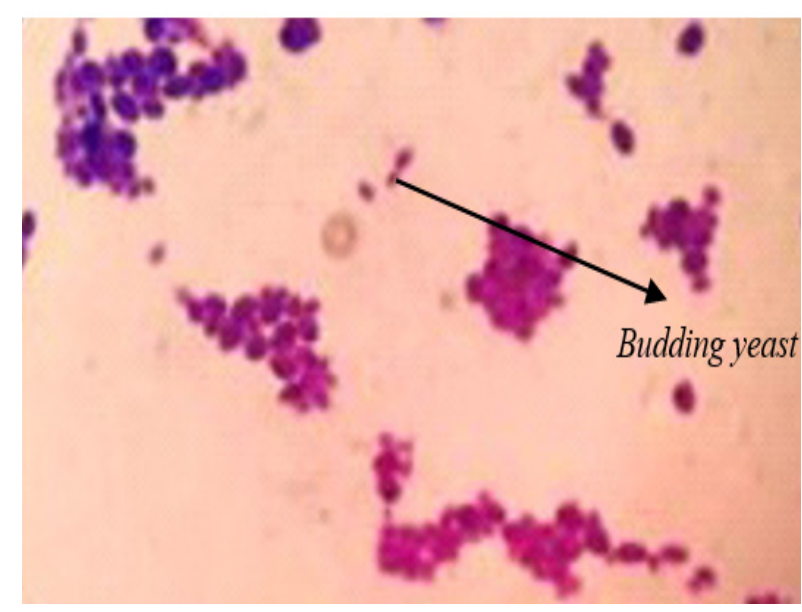

Figure 2. Candida albicans gram-positive stain for $2-3$ hours..$^{15}$ The results confirmed positive if on microscopic examination found cell shape that germinate, racket-like shaped (Germ tube). From colony identification result can be ascertained the mold growing was Candida albicans. Activities

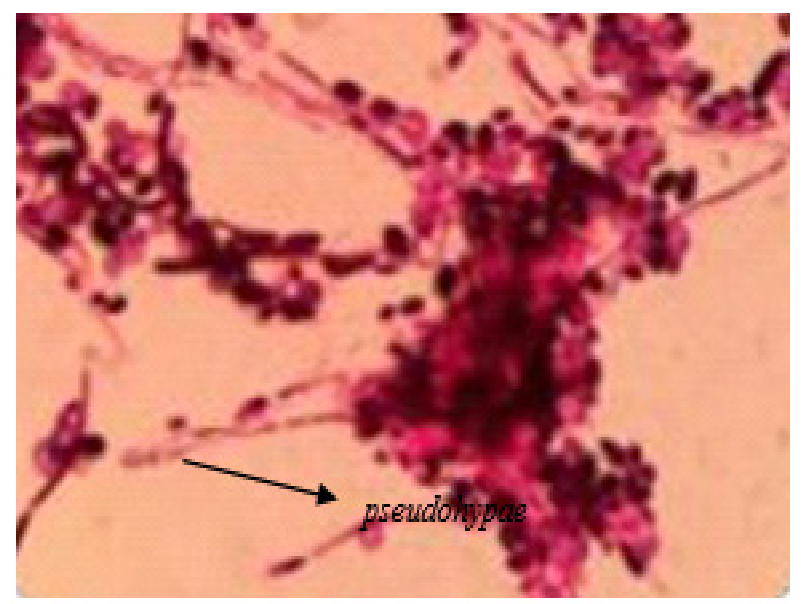

Figure 1. Candida albicans culturing after 7 days

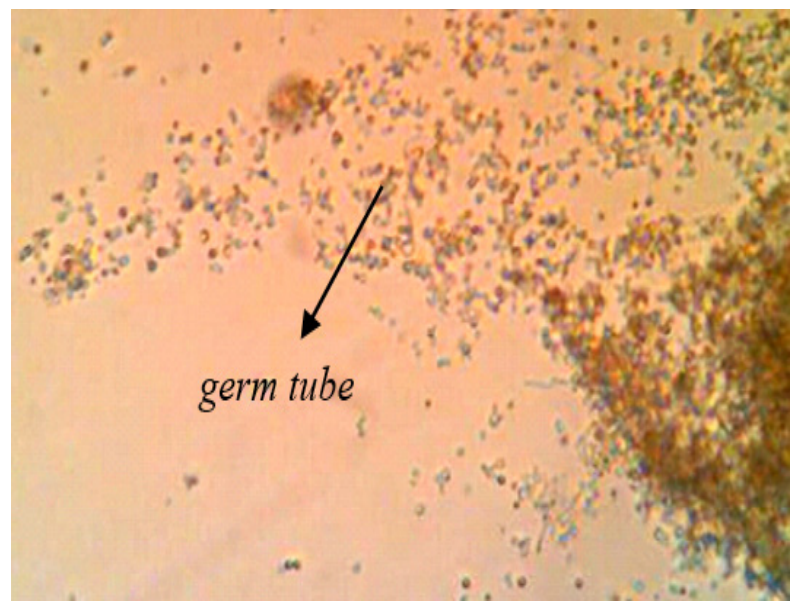

Figure 3. Germ tube test

Table 3. The growth inhibition zone diameter of Candida albicans by using Phaleria macrocarpa leaves extract

\begin{tabular}{cccccc}
\hline \multirow{2}{*}{$\begin{array}{c}\text { Experiment/ } \\
\text { Repetition }\end{array}$} & \multicolumn{6}{c}{$\begin{array}{c}\text { Inhibition zone diameter }(\mathrm{mm}) \text { in various concentration of } \\
\text { Phaleria macrocarpa leaves extract }\end{array}$} & $\begin{array}{c}\text { Ketoconazole } \\
\text { Control (+) }\end{array}$ \\
\cline { 2 - 5 } & $\mathbf{1 0 \%}$ & $\mathbf{2 0 \%}$ & $\mathbf{4 0 \%}$ & $\mathbf{8 0 \%}$ & \\
\hline I & - & - & 9.3 & 18.1 & \\
II & - & - & 9.2 & 18.5 & 20.1 \\
III & - & - & 9.0 & 18.2 & \\
IV & - & - & 9.2 & 17.5 & \\
V & - & - & 9.3 & 17.7 & 20.1 \\
VI & - & - & 9.3 & 18.1 & \\
\hline Mean & & & 9.217 & 18.017 & \\
\hline
\end{tabular}


Table 4. Descriptive analysis of Phaleria macrocarpa leaves extract activities against Candida albicans

\begin{tabular}{|c|c|c|c|c|c|}
\hline \multirow{2}{*}{$\begin{array}{c}\text { Concentration } \\
\text { Variable }\end{array}$} & \multirow{2}{*}{$N$} & \multirow{2}{*}{ Mean } & \multirow{2}{*}{$\begin{array}{l}\text { Deviation } \\
\text { Standard }\end{array}$} & \multicolumn{2}{|c|}{$95 \% \mathrm{Cl}$} \\
\hline & & & & Lower & Upper \\
\hline $10 \%$ & 6 & 0.00 & 0.000 & 0.000 & 0.000 \\
\hline $20 \%$ & 6 & 0.00 & 0.000 & 0.000 & 0.000 \\
\hline $40 \%$ & 6 & 9.217 & 0.1169 & 9.094 & 9.339 \\
\hline $80 \%$ & 6 & 18.017 & 0.3601 & 17.639 & 18.395 \\
\hline Total & 24 & 6.808 & 7.6486 & 3.579 & 10.038 \\
\hline
\end{tabular}

test of Phaleria macrocarpa leaves extract against Candida albicans of HIV/AIDS patients, on the concentration of $10,20,40$ and $80 \%$ obtained the following results:

The results of the experimental data were analyzed using statistical program in order to knowing the anti-fungal potency of Phaleria macrocarpa leaves extract against Candida albicans of patients with HIV/AIDS at concentrations of 10, 20, 40 and $80 \%$. Previously, normality test was done by using the Shapiro-Wilk test to determine whether the data was normally distributed or not. Based on the normality test gained that $p=0.000$ where the $p$-value was less than $0.05(p<0.05)$, means that the data obtained was not normally distributed. Because the data was not normally distributed then the non-parametric Kruskal-Wallis test used to see the inhibition zone of Phaleria macrocarpa leaves extract against Candida albicans.

\section{DISCUSSION}

On the examination of Phaleria macrocarpa leaves extract against Candida albicans, at the concentration of $10,20,40$, and $80 \%$, obtained the average values such as follows: at the concentrations of 10 and $20 \%$ found no inhibition zone; at the concentration of $40 \%$ obtained the inhibition zone average value of $9.217 \mathrm{~mm}$; and at the concentration of $80 \%$ obtained the inhibition zone average value of $18.017 \mathrm{~mm}$. Based on the average value can be concluded that the higher the concentration levels of the Phaleria macrocarpa leaves extract the higher the inhibition zone against the growth of the Candida albicans, where the highest inhibition zone power obtained at concentration of $80 \%$. From the statistical test results using Kurskall-Wallis test obtained sig $=0.000<0.05$, and concluded that there were differences on Phaleria macrocarpa leaves extract against Candida albicans at concentration of 10 , 20, 40 and $80 \%$.

Research on the same extract also has been done by Yunanto ${ }^{5}$ about the infusum inhibition zone test of Phaleria macrocarpa leaves against the growth of Streptococcus mutans. The results showed that Phaleria macrocarpa leaves infusum has the inhibition potency against the growth of Streptococcus mutans, with the highest inhibition level at the concentration of $50 \%$. Suryani and Selly ${ }^{6}$ research showed that Phaleria macrocarpa leaves infusum having antibacterial potency against Staphylococcus aureus with MIC 3.125 gram\% and MKC 6.25 gram\%, but did not has antibacterial potency against Eschericia coli with MIC greater than 25 gram\%.

Another research done by Wijaya and Hendra $^{1}$ about in vitro test of anti-bacterial effect of Phaleria macrocarpa vernal pulp against Klebsiella pneumoniae. The results showed that the ethyl acetate and ethanol extract of Phaleria macrocarpa vernal pulp capable to inhibit the growth of Klebsiella pneumoniae bacteria, with MIC of both extract were at concentration of $1 \%$ and the ampicillin antibiotic equality value of ethyl acetate and ethanol extract of Phaleria macrocarpa vernal pulp against Klebsiella pneumoniae respectively were 0.053 and $0.003 \%$.

Compared with other antifungal research of other plantation, Phaleria macrocarpa leaves had more effective antifungal potency compared with Bay leaves extract, as found on Bhaskara ${ }^{16}$ research about invitro antifungal potency test of Bay (Syzygium polianthum) leaves ethanol extract against Candida albicans. The results showed that the ethanol extract of Bay leaves has antifungal potency against Candida albicans at concentration of 40,80 , and $100 \%$, with each inhibitory zone diameter respectively 7,9 , and 11 . From another 
research done by $\mathrm{Nahak}^{17}$ found that ethanol extract of Beluntas (Pluchea indica L.) leaves wa capable to inhibit the growth of Streptococcus mutans bacteria, at concentration of 25,50 , 75 , and $100 \%$, with the inhibitory zone average value respectively $11.2,14.2,15.6$ and $19.2 \mathrm{~mm}$. Minimum concentration that able to inhibit the bacteria growth was $25 \%$.

Another research done by Kusrini, Khairul, and Bambang ${ }^{18}$, about the antimycosis potential of several Indonesian medicinal plantation against Candida albicans mycosis, where the ethanol extract of Annona squamosa L. (Srikaya), Phyllantus acidus L. (Ceremai) and Phaleria macrocarpa (Mahkota Dewa) had larger antifungicidal potency compared with dichloromethane extract. The highest antimycosis activity against Candida albicans as compared to comparator antibiotics showed by the ethanol extract of Annona squamosa $L$, having the highest activity equal with $11.565,11$ ug of Ketoconazole, and Phaleria macrocarpa extract equal with 2.344,46 ug of Ketoconazole.

The effectivity of Phaleria macrocarpa leaves extract towards the inhibition potency of Candida albicans due to so many chemical compounds contained in this plant which was very useful to inhibit the growth of Candida albicans. The same thing presented by Hariana ${ }^{3}$, that the leaves of Phaleria macrocarpa contained antihistamines, alkaloids, saponins, and polyphenols (lignans). Saponin as an antimicrobial agent against bacteria, viruses, fungi, and yeast. ${ }^{4}$ The active compositions of Phaleria macrocarpa were tannins, flavonoids, saponins and alkaloids. ${ }^{2}$

On HIV/AIDS patients, Phaleria macrocarpa leaves are very useful because it's ability to inhibit the fungus growth. Candida albicans is one of the microorganisms that act as normal flora in the human body and also not harmful, but causes most infections in human, mostly localized infection such as oral and vaginal infections. ${ }^{9}$ According to Akpan $^{10}$, many fungal infection caused by Candida species, especially Candida albicans, with the rate of $95 \%$ in the oral cavity of HIV/AIDS patients. The most common HIV-related oral cavity lesions is candidiasis, particularly caused by Candida albicans. In a study reported that oral candidiasis occurs in $17-43 \%$ of patients with HIV infection, and more than $90 \%$ of patients with AIDS. ${ }^{19}$
From the research data of Phaleria macrocarpa leaves can be determined that at concentration of $40 \%$ the inhibition zone was $9.217 \mathrm{~mm}$, classified as average criteria, and at concentration of $80 \%$ the inhibition zone was $18.017 \mathrm{~mm}$, classified as powerful criteria. This determination based on Davis and Stout in Pratama ${ }^{19}$, reported that the provisions of antifungal inhibitory criteria were as follows: inhibitory zone of $20 \mathrm{~mm}$ or more includes to very powerful criteria, inhibitory zone of $10-20 \mathrm{~mm}$ includes to powerful criteria, inhibitory zone of 5-10 mm includes to average criteria, and inhibitory zone of $5 \mathrm{~mm}$ or less includes to weak criteria.

From the research result analysis, there were significant differences of Phaleria macrocarpa leaves extract against Candida albicans at concentration of $10,20,40$, and $80 \%$. The highest inhibitory happened at the concentration of $80 \%$, inhibitory average value $18.017 \mathrm{~mm}$. The effectivity of Phaleria macrocarpa leaves extract use will be very helpful for HIV patients because it's ability to inhibit fungus growth on patient's oral cavity, so that it can become an alternative natural medication to reduce the Candida albicans fungus in patients with HIV.

\section{CONCLUSION}

The higher level of the Phaleria macrocarpa leaves extract concentration, the higher inhibition zone diameter against Candida albicans, with the highest in concentration $80 \%$.

\section{REFERENCES}

1. Wijaya $\mathrm{S}$, Nopriansyah $\mathrm{H}$. Uji invitro efek antibakteri ekstrak daging muda buah Mahkota Dewa (Phaleria macrocarpa) terhadap Klebsiella pneumoniae. Palembang: Fakultas Kedokteran Universitas Sriwijaya; JIMKI 2012. p. 2-3.

2. Artayanti PR. Efektifitas antibakteri ekstrak buah Mahkota Dewa (Phaleria macrocarpa) sebagai bahan alternatif sterilisasi saluran akar gigi terhadap bakteri mix saluran akar gigi. Minor thesis, Denpasar: Fakultas Kedokteran Gigi Universitas Mahasaraswati; 2014. p. 3-11.

3. Hariana A. Tumbuhan obat dan khasiatnya. Cet. 2 (Edisi revisi)-Jakarta: Penebar Swadaya; 
2015. p. 225.

4. Suwandi T. Pengembangan potensi antibakteri kelopak bunga Hibiscus sabdariffa L. (Rosela) terhadap Streptococcus sanguinis penginduksi gingivitis menuju obat herbal terstandar. Dissertation. Jakarta: Fakultas Kedokteran Gigi. Universitas Indonesia. 2012. p. 37-8.

5. Yunanto K. Uji zona hambat infusum daun Mahkota Dewa (Phaleria papuana Warb. Var. Wichannii) pada pertumbuhan Streptococcus mutans. Minor thesis. Jember: Fakultas Kedokteran Gigi; 2007. p. 7-8.

6. Suryani L, Selly S. Daya antibakteri infisa daun Mahkota Dewa (Phaleria macrocarpa) terhadap Staphylococcus aureus dan Eschericia coli. J Mut Med 2007;5(1):23-8.

7. Wulandari D. Pengaruh perasan daging buah segar Mahkota Dewa (Phaleria macrocarpa (scheff) boerl) terhadap penurunan glukosa darah kelinci jantan New Zealand yang diberi toleransi glukosa oral. Minor thesis, Surakarta: Fakultas Farmasi UMS; 2009. p. 3-6.

8. Rostinawati T. Uji aktifitas hasil penyarian biji Mahkota Dewa (Phaleria macrocarpa [scheff.]) terhadap beberapa mikroba penyebab infeksi kulit. Karya Ilmiah. Bandung: Fakultas Farmasi UNPAD; 2007. p. 3.

9. Hidayat U. Sudarmin, Kusoro S. Uji aktivitas senyawa hasil oksidasi kariofilena dengan $\mathrm{KMnO}_{4}$ terhadap Candida albicans. Indo J Chem Scie 2012. p. 176.

10. Akpan A, Morgan R. Oral candidiasis. Postgrad Med J 2002;78:455-9.

11. Radithia D, Bagus S. Karakterisasi protein tat HIV pemicu pembentukan hifa Candida albicans sebagai dasar desain blocker untuk mencegah oral candidiasis pada infeksi HIV. Research report. Surabaya: Universitas Airlangga 2009. p. 3-4.

12. Kalalo JGK, Heedy M, Tjitrosantoso, Lily Ranti-Goenawi. Studi penatalaksanaan terapi pada penderita HIV/AIDS di Klinik VCT Rumah Sakit Kota Manado. J Farmasi 2012. p. 98-9.

13. Tanjong A. Pengaruh konsentrasi esktrak kelopak bunga Rosella (Hibiscus sabdarifa L) terhadap koloni Candida albicans yang terdapat pada plat gigi tiruan. Minor thesis, Makasar: Fakultas Kedokteran Gigi Universitas Hasanudin 2011. p. 57-8.

14. Riskillah AG. Candida albicans. Pekan baru: Faculty of Medicine University of Riau; 2010. p. 1-2.

15. Mulyati RW, Widyuningsih, Widiastuti, Pujdi KS. Isolasi spesies Candida dari tinja penderita HIV/AIDS. Fakultas Kedokteran. Jurnal Makara Kesehatan 2002;6(2):52.

16. Bhaskara GY. Uji daya antifungi ekstrak etanol daun salam (Syzygium polianthum [Wight] Walp.) terhadap Candida albicans ATCC 10231 secara in vitro. Minor thesis, Surakarta: Fakultas Kedokteran Universitas Muhammadiyah Surakarta 2012. p. 8-9.

17. Nahak MM. Ekstrak daun Beluntas (Pluchea Indica L) dapat menghambat pertumbuhan bakteri Streptococcus mutans. Thesis, Denpasar: Universitas Udayana 2012. p. 67-72.

18. Kusrini D, Khairul A, Bambang C. Potensi antimikosis beberapa tumbuhan obat Indonesia. Jurnal Laboratorium Kimia Organik FMIPA Universitas Diponegoro. 2006;10(3):1-2.

19. David AS. Oral manifestation of HIV disease. J New Jersey School 1998;65:322-32. 